\title{
Cost and profit analysis of sour cherry production for industrial purposes in Hungary
}

\author{
Apáti, F, Nyéki, J., Szabó, Z., Soltész, M., Szabó, V. \& Felföldi, J. \\ University of Debrecen Centre for Agricultural Sciences and Engineering \\ H-4032 Debrecen Böszörményi St. 138
}

\begin{abstract}
Summary: Our main objective in this present study is to evaluate the profitability and efficiency of sour cherry production by a complex economic analysis of its technological process. We concluded that the per kilogram prime costs range between 80 to $90 \mathrm{HUF} / \mathrm{kg}$ in case of sour cherry for industrial purposes. On this basis, it is clear that the 50 to $90 \mathrm{HUF} / \mathrm{kg}$ regular selling prices of previous years do not make profitable production possible. Under the present market conditions even considering per hectare average yields of 10 to 15 tons the establishment of sour cherry orchards is not economical, the internal rate of return is below the interests of money-market and the recovery will not be happened even during the whole life-time of the orchard. In this way the domestic enterprises should not only raise the yields but realize technological changes (e.g. mechanic harvesting) in order to decrease the production costs in a significant way and to maintain a profitable sour cherry production. It is expected that the enterprise farming on great land (several ten hectares), being settled for mechanic harvesting (subordinating everything to this), reaching yields of 15 to 20 tons per hectare, producing on high technological and input levels, having specialized knowledge will stay on the sour cherry market far in the future.
\end{abstract}

Key words: sour cherry production, economic efficiency, competitiveness

\section{Introduction}

Sour cherry production has not belonged to the success branches of the Hungarian horticulture since last years. The present Hungarian sour cherry branch is characterized by low purchase prices, much lower than the prime cost, yields left on the trees because of lack of market, hundreds and thousands of neglected and uncared orchards and bitterness of sour cherry producers. Under these condition it is hard to say or do something wise but by analyzing the cost and profit conditions of the production we try to have a deeper look into the evolved situation, and make it see, because it is sure that the basis of competitiveness is profitability. Without a proper profitability any activity is sentenced to death, thus it is extremely relevant to investigate this, and it is one of the tools for defining breaking points. Competitiveness is primarily determined by the efficiency of the production (Felföldi, 2007), as a consequence farm economic analysis focusing on this is the most important task in these orchards as well.

\section{Objectives}

Starting from the above mentioned our main objective is to evaluate the profitability and efficiency of sour cherry production by a complex economic analysis of its technological process. First, the cost, yield and profit conditions of an average year highlighted from the period of whole yields are introduced, and then an investment economic efficiency analysis comes relating to the whole life-time of the orchard. This second one has a significant importance as an orchard investment takes 15 to 20 years that is the activity needs a very long period, thus the profitability and efficiency of the whole investment cannot be evaluated by economic analyzing of a single year. Short-term analyses focusing on one year do not reflect the feature of the plantations meaning the fact that their establishment requires a huge single investment, their cultivation needs high inputs (Buzás, 2001), revenues hardly occur during the first years, and the profitability further on ranges between a wide interval due to several factors.

\section{Material and method}

The complex cost and profit analysis of the domestic sour cherry production was carried out for up-to-date and cared orchards of good state having traditional cultivating system. Such an orchard is characterized by high yields (about 8 to 12 tons per hectare in average of many years, up to 15 to 20 tons per hectare in good years), excellent quality (size, maturity) and high level of inputs. It must be highlighted that these parameters do not reflect the Hungarian average but the best orchards which covers at least 2000 to 3000 hectares from the plantation area of 16000 hectares. From the point of view of the competitive production these must be considered as standard to be followed. The parameters of the orchard type 
serving the basis of our analysis are: Mahaleb root stock, funnel-shaped or combined crown form and $6,0 \times 4,0 \mathrm{~m}$ spatial position, which equals with 417 trees per hectare. The used varieties are mainly those which are most frequently used in Hungary ("Újfehértói fürtös", "Kántorjánosi fürtös", "Debreceni bőtermő"). There is not any irrigation system; the technology of harvesting is manual.

There are several indicators available for investment profitability analysis, but dynamic indicators provide the most precise results (Szücs, 2004, Nábrádi and Szöllösi, 2007, Brealey et al., 2006). From these NPV (Net Present Value), DPP (Discounted Payback Period) and IRR (Internal Rate of Return) are evaluated.

The Net Present Value (NPV) reflects the fact that how much higher profit our investment generates in comparison with a certain alternative investment opportunity in present value (these alternative opportunities are generally considered as state papers or bank deposit as in this study). The profit to capital yield of the alternative investment is expressed by a calculative interest rate. This rate, which is the interest need of the fixed capital, was $7 \%$ in our calculations, which presently equals with the interest rate of state papers (Illés, 2002). The Discounted Payback Period (DPP) is the year when the cash flow of the plantation in present value, which is otherwise the NPV, reaches or exceeds the zero. This means that the revenues of our orchard first recover the whole expenses relating to the investment and the operation. The Internal Rate of Return (IRR), which is considered as a one-year, average dynamic profit to capital ratio, reflects that how much interest rate could have been used when investing our money invested in plantation establishment to a bank or state papers for a 20year-period, for the fact that this money should generate the same profit in present value as our orchard during the whole life-time (during also 20 years).

\section{Results and their evaluation}

\section{Input and production cost}

In case of the orchard type and conditions above mentioned, the direct production costs take up of 900 thousands HUF calculated to a per hectare yield of 12 tons, which means a direct prime cost of 76,1 HUF/kg (Table 1). Harvesting (manual picking) is far the most outstanding phase among the phases by its ratio of 50 to $60 \%$. Besides, plant protection contributes to costs by 15 to $20 \%$, the cost modifying role of the other phases is not so determent.

Calculations were carried out even in cost-type structure parallel to analyzing cost structure by phases relating to the technology of sour cherry production. The calculation was supplemented by overhead costs; altogether the per hectare cost is about 1 million HUF (Table 2).

The most significant cost is the personal cost in sour cherry production constituting $60 \%$ from the total production
Table 1. The costs of sour cherry production by working phases (per hectare)

\begin{tabular}{|l|c|c|c|}
\hline \multicolumn{1}{|c|}{ Phases } & $\begin{array}{c}\text { Cost } \\
\text { (thousand } \\
\text { HUF/ha) }\end{array}$ & $\begin{array}{c}\text { Cost } \\
\text { (HUF/kg) }\end{array}$ & $\begin{array}{c}\text { Distribution } \\
(\mathbf{\%})\end{array}$ \\
\hline Pruning & 44 & 3,7 & 5 \\
\hline Soil and row cultivation & 16 & 1,3 & 2 \\
\hline Fertilizing & 71 & 5,9 & 8 \\
\hline Plant protection & 168 & 14,0 & 18 \\
\hline Harvesting & 496 & 41,3 & 54 \\
\hline Depreciation of the orchard & 118 & 9,9 & 13 \\
\hline DIRECT PRODUCTION COST & $\mathbf{9 1 3}$ & $\mathbf{7 6 , 1}$ & $\mathbf{1 0 0}$ \\
\hline
\end{tabular}

Source: own calculation

Table 2. Costs of sour cherry production by cost-type-structure (per hectare)

\begin{tabular}{|l|c|c|c|}
\hline \multicolumn{1}{|c|}{ Phases } & $\begin{array}{c}\text { Cost } \\
\text { (thousand } \\
\text { HUF/ha) }\end{array}$ & $\begin{array}{c}\text { Cost } \\
\text { (HUF/kg) }\end{array}$ & $\begin{array}{c}\text { Distribution } \\
(\boldsymbol{\%})\end{array}$ \\
\hline Material cost & 184 & 15,3 & 20 \\
Labour cost & 527 & 43,9 & 58 \\
Machinery cost & 84 & 7,0 & 9 \\
Depreciation of orchard & 118 & 9,9 & 13 \\
Other direct cost & 0 & 0,0 & 0 \\
DIRECT PRODUCTION COST & 913 & 76,1 & 100 \\
Overhead cost & 91 & 7,6 & \\
TOTAL PRODUCTION COST & 1004 & 83,7 & \\
\hline
\end{tabular}

Source: own calculation

cost. This is followed by the material cost contributing by $20 \%$ to the production cost. Machinery cost and depreciation cost represent almost a same ratio. Other direct costs (insurance cost, land rent) were not calculated as they are not typical in sour cherry production, but they may increase production costs by 100 to 150 thousand HUF.

Material costs include only the costs of plant protecting agents and chemical fertilizers, from which the ratio of plant protecting agents is higher constituting two third of the material costs. Only the cost of picking takes up of 85 to $90 \%$ of labour cost. This cost type, however, depends wholly on yields (that is this cost as a whole is a variable cost) thus this value may be significantly modified by the change of the yields. Other labour work besides pruning belonging to the maintenance of the orchard does not represent a significant part. The only determining phase is picking. The machinery needs of plant protection (50 to 55\%), soil and row cultivation (15 to $20 \%$ ) and harvesting (10 to $15 \%$ ) are outstanding from machinery costs.

\section{Yield, revenue, production value}

Table 3 reflects the revenue calculation typical to sour cherry production. The major part of the harvest of 12 tons per hectare is for industrial processing, the ratio of sour cherry being sold in fresh market does not exceed the 5 to $10 \%$ in national average, and thus it was neglected. Selling 
happens immediately after picking, in this way storing costs are not calculated. It must be highlighted that yields and selling prices in the calculation represent the averages of the past five years. Regarding every factor per hectare revenue of 1,0 to 1,1 million HUF may be reached in sour cherry production. It is essential, however, that this value may reflect a significant fluctuation year by year.

Table 3. Revenue and production value in sour cherry production

\begin{tabular}{|l|c|r|}
\hline \multicolumn{1}{|c|}{ Denomination } & Unit & Value \\
\hline Total yield & t/ha & 12,0 \\
\hline Selling price & HUF/kg & 90,0 \\
\hline Total revenuethousand & HUF & 1080,0 \\
\hline SAPS & thousand HUF & 25,0 \\
\hline PRODUCTION VALUE & thousand HUF & $\mathbf{1 1 0 5 , 0}$ \\
\hline
\end{tabular}

Source: own calculation

Basically there are two direct payments in sour cherry production which can be calculated. The value of the SAPS is rather low (25 thousand HUF per hectare), while agricultural-environmental subsidy for the method of environmental friendly production is near 100 thousand HUF per hectare which cannot be neglected from the production value, but here and now it was not calculated as its appearance is rather accidental just like other direct cost among the cost. Aggregating revenue and subsidies a production value of 1,1 million HUF is reached, which may be considered as an average value for enterprises producing on good standard and for the past five years.

\section{Profit, profitability}

Table 4 shows the calculation of profit by using the data of the already introduced production cost and production value. Summarizing the data of sour cherry production only a contribution of 150 to 200 thousand HUF may be expected from even ventures producing on good standards under present price conditions. After deducting overhead costs, the net profit is hardly positive, it takes up of 100 thousands HUF per hectare.

Table 4. Profit in sour cherry productionn

\begin{tabular}{|l|c|c|}
\hline \multicolumn{1}{|c|}{ Denomination } & Unit & Value \\
\hline PRODUCTION VALUE & thousand HUF & $\mathbf{1 1 0 5 , 0}$ \\
\hline Direct production cost & thousand HUF & 913,0 \\
\hline CONTRIBUTION & thousand HUF & $\mathbf{1 9 2 , 0}$ \\
\hline Overhead costthousand & HUF & 91,0 \\
\hline Total production cost & thousand HUF & 1004,0 \\
\hline NET PROFIT & thousand HUF & 101,0 \\
\hline Cost rated profitability & $\%$ & 10,0 \\
\hline Direct prime cost & HUF/kg & 76,1 \\
\hline Prime cost & HUF/kg & $\mathbf{8 3 , 7}$ \\
\hline
\end{tabular}

Source: own calculation

\section{The economic efficiency of sour cherry production}

Figure 1 illustrates the cumulated value of the generated profit for the whole life-time of the sour cherry orchard calculated in present value of money.

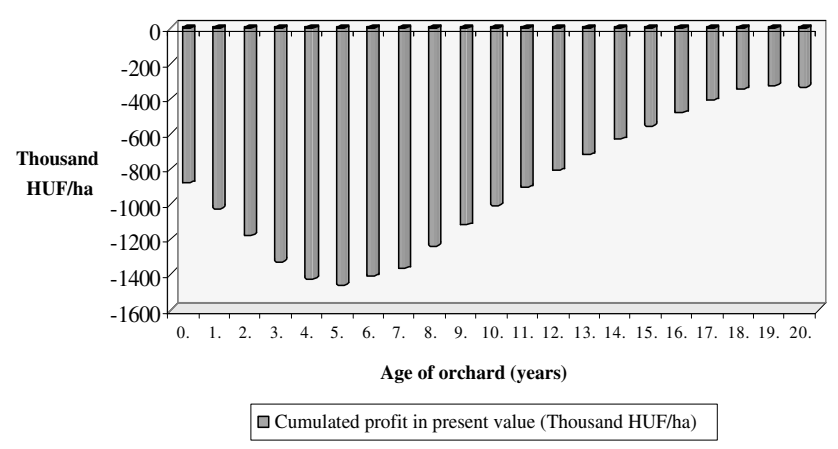

Figure 1: The Cumulated Discounted Profit (NPV) of the Sour Cherry Orchard during the Life-Time $(r=7 \%)$

On the basis of data in Figure 1 and Table 5, sour cherry production does not show any economic efficiency under the present cost condition, selling prices of $90 \mathrm{HUF} / \mathrm{kg}$ and average yields of 12 tons per hectare. The payback period is more than 20 years that is our orchard does not recover even during its whole life-time, though our expectations would be 9 to 11 years. Its internal rate of return is $4,5 \%$, which means by comparing with the interest rates of 7 to $12 \%$ in the money market that our capital generates much lower than in banks or state papers. Thus it does not meet our requirement of 15 to $20 \%$ profitability considered as good expectations, and it does not comply with even the minimal efficiency assumptions.

Table 5. Indicators of economic efficiency of orchard investment

\begin{tabular}{|l|c|c|}
\hline \multicolumn{1}{|c|}{ Denomination } & Unit & Value \\
\hline Production value (total revenue) & thousand HUF/ha & 1105 \\
\hline Production costthousand & HUF/ha & 1004 \\
\hline NET PROFIT (profit before tax) & thousand HUF/ha & $\mathbf{1 0 1}$ \\
\hline Prime cost & HUF/kg & 84 \\
\hline $\begin{array}{l}\text { DISCOUNTED PAYBACK } \\
\text { PERIOD (DPP) }\end{array}$ & year & $\begin{array}{c}\text { does not } \\
\text { recover }\end{array}$ \\
\hline $\begin{array}{l}\text { INTERNAL RATE OF RETURN } \\
\text { (IRR) }\end{array}$ & $\mathbf{\%}$ & $\mathbf{4 , 5}$ \\
\hline
\end{tabular}

Source: own calculation

\section{Conclusions, recommendations}

The per kilogram prime costs range between 80 to 90 $\mathrm{HUF} / \mathrm{kg}$ in case of sour cherry for industrial purposes. On this basis, it is clear that 50 to $90 \mathrm{HUF} / \mathrm{kg}$ regular selling prices of previous years do not make profitable production possible. Twice during the five past years prices appeared in the lane meaning deficit, twice around the prime cost and only 2007 was the year which could make high profit 
possible, but because of total frost damage most of the enterprises faced with no product at all. Summarizing all these experiences sour cherry production hardly generated profit even in up-to-date ventures producing on high standard during the five past years. It contributes to the fact that producers have to move further to any direction, as the present supply-demand conditions, including competitive ventures determining prices and other economic processes in the market economy to the greatest extent hardly make efficient production possible. It is clear that in order to maintain efficient sour cherry production besides increasing yields technological changes (e.g. mechanic harvesting) are needed for decreasing the production costs in a significant way if the prices of the past years will not rise significantly (which cannot be expected).

It is expected that the enterprise farming on great land (several ten hectares), being settled for mechanic harvesting (subordinating everything to this), reaching yields of 15 to 20 tons per hectare, producing on high technological and input levels, having specialized knowledge will stay on the sour cherry market far in the future.

Orchards of small area (a few tithes or 1 to 2 hectares) as well as small gardens have little chances to stay in the market, as mechanic harvesting in small area is not efficient by using own machines. Furthermore, hiring paid workers may be organized in a difficult way. It is a much bigger problem than this that the improper health status (monilia, blumeriella) arising from the capital insufficiency of small gardens predestinates low yields which do not ensure economic efficiency.

\section{References}

Brealey, R. A., Myers, S. C. \& Allen, F. (2006): Corporate Finance. Eight Edition, McGraw-Hill, 84-143. p., 244-272. p.

Buzás, Gy. (2001): Az ültetvényes ágazatok ökonómiája. (In: Mezőgazdasági üzemtan II. Szerk: Pfau-Széles) Mezőgazdasági Szaktudás Kiadó, 260-264. p.

Felföldi, J. (2007): A gazdálkodási teljesítmény elemzése. (In.: Farmmenedzsment ismeretek. Szerk.: Felföldi J.) InterClaster Kht. Kecskemét

Illés, M. (2002): A beruházások gazdaságossága. (In: Vezetői gazdaságtan. Szerk.: Illés M.) Kossuth Kiadó 2002. 115-162. p.

Nábrádi, A. \& Szőllősi, L. (2007): Key aspects of investment analysis. APSTRACT Applied Studies in Agribussiness and Commerce, 1 (1): 53-56.

Szücs, I. (2004): Beruházások gazdasági elemzése. (In.: Gyakorlati alkalmazások - Az üzleti tervezés gyakorlata. Szerk.: Szücs I. Nagy L.). Campus Kiadó. Debrecen, 129-139. p. 